\title{
Age and growth of larval cod and haddock on Georges Bank during 1995 and 1996
}

\author{
J. Green*, R. Jones, S. Brownell \\ National Oceanic and Atmospheric Administration, National Marine Fisheries Service, Northeast Fisheries Science Center, \\ 28 Tarzwell Drive, Narragansett, Rhode Island 02882-1199, USA
}

\begin{abstract}
Growth rates of larval cod Gadus morhua and haddock Melanogrammus aeglefinus were estimated based on collections in winter and spring of 1995 and 1996 during the US Global Ocean Ecosystem Dynamics (GLOBEC) Georges Bank Program. Growth was determined using length-at-age data derived from otolith increments to indicate age in days from hatching. Growth varied significantly among months and between 1995 and 1996. In general, cod growth exceeded $0.2 \mathrm{~mm} \mathrm{~d}^{-1}$ and reached a maximum growth rate of $0.7 \mathrm{~mm} \mathrm{~d}^{-1}$ in May 1996. Haddock growth was also greater than $0.2 \mathrm{~mm} \mathrm{~d}^{-1}$ with a peak of $0.5 \mathrm{~mm} \mathrm{~d}^{-1}$ in June 1995. For cod, instantaneous growth rates of 3.3 to $3.5 \% \mathrm{~d}^{-1}$ were higher than those published previously for the Georges Bank region. Haddock growth was comparable to that of cod in $1995\left(3.3 \% \mathrm{~d}^{-1}\right)$, but a higher growth rate for haddock $\left(3.5 \% \mathrm{~d}^{-1}\right)$ in 1996 was probably due to an under-representation of larger sizes in the data available. Increased size-at-age was associated with higher temperatures for both species; however, the effect of temperature on growth appears to have decreased in May as temperatures exceeded $6^{\circ} \mathrm{C}$ and approached $8^{\circ} \mathrm{C}$. Insufficient numbers of larvae of either species were available in May of 1996 for a similar analysis; however, cod growth during May 1996 was the most rapid observed in this study $\left(0.7 \mathrm{~mm} \mathrm{~d}^{-1}\right)$. This corresponded to a period of high production of suitable food organisms, early stage Calanus finmarchicus, in May 1996 resulting from cooler winter temperatures and late warming after the winter of 1996, suggesting that cooler temperatures favor a prolonged period of food production for larvae and better conditions for growth late in the larval period.
\end{abstract}

KEY WORDS: Cod larvae $\cdot$ Haddock larvae $\cdot$ Temperature variability $\cdot$ Growth $\cdot$ Otolith Resale or republication not permitted without written consent of the publisher

\section{INTRODUCTION}

The GLOBal Ocean ECosystem Dynamics Program (US GLOBEC 1991) for Georges Bank seeks to characterize and explain inter-annual variability in survival for larval cod Gadus morhua and haddock Melanogrammus aeglefinus, and their important prey, the copepods Calanus finmarchicus and Pseudocalanus spp. in the context of biological and physical change in the environment, particularly as driven by climate change. The program has employed a strategy of investigation that included multidisciplinary cruises to conduct site-specific studies to investigate biological and physical processes affecting target species, and broad-area surveys to encompass population level parameters of the target species. A description of the goals and methods of the program are given in US
GLOBEC Northwest Atlantic Implementation Plan (US GLOBEC 1992). A key factor in survival of young fishes is said to be rapid growth through the early stages of development when vulnerability to predation, starvation and advective loss from suitable nursery areas is highest (Hjort 1914, Sinclair 1988, Bailey \& Houde 1989, Cushing 1990, Houde 1997). Cod and haddock are 2 of the principal commercially exploited groundfish on Georges Bank where these stocks represent the southernmost extension of their distribution (Morse et al. 1987, Planque \& Fredou 1999) and are most likely to be affected by global climate change.

Larval growth of cod and haddock has been studied in the laboratory (Laurence 1978, Geffen 1995) and in the field (Bolz \& Lough 1983, 1988, Campana \& Hurley 1989), and has been extensively modeled (Ellertsen et al. 1981, Laurence \& Lough 1985, Werner et al. 1996, 
Leising \& Franks 1999). Generally, laboratory studies have allowed description of growth in terms of weight increase per unit time from live specimens, while field studies have, of necessity, expressed growth in terms of length increase based on preserved specimens. Recent growth can be indexed in biochemical terms as RNA/DNA in larval tissue and has been used to compare short-term growing conditions in processoriented studies (Buckley \& Lough 1987). On Georges Bank, previous age and growth studies (Bolz \& Lough $1983,1988)$ have not sampled throughout the spawning season or have not covered the Bank completely (Campana \& Hurley 1989) and thus, have not encompassed the full range of temporal and spatial variability of growth within a year class. The object of this study was to determine larval cod and haddock growth rates on a Bank-wide scale by using samples from repeated, closely spaced cruises ( every $2 \mathrm{wk}$ ) in order to characterize growth during the period of the study using methods similar to those of Bolz \& Lough (1983). The results presented here were generated from observations of the early growth of the 2 target fish species during the first $2 \mathrm{yr}$ of the US GLOBEC Georges Bank Program. Larval growth is compared among months and between 1995 and 1996 in the context of temperature and prey availability.

\section{MATERIALS AND METHODS}

Ichthyoplankton samples were taken in late winter and early spring of 1995 and 1996 during broad-scale surveys of the US GLOBEC Georges Bank Program. In 1995, broad-scale surveys were conducted from February through July, while in 1996 sampling was from January through June. A series of 38 to 41 standard stations were visited on each survey that generally covered Georges Bank and adjacent waters with rela- tively uniform coverage, except in shoal areas (Fig. 1). At each standard station, ichthyoplankton was sampled by using selected nets from a Multiple Opening and Closing Net Environmental Sampling System (MOCNESS) with a $1 \mathrm{~m}^{2}$ mouth opening and a $61 \mathrm{~cm}$ diameter Bongo sampler, each fitted with $335 \mu \mathrm{m}$ mesh nets. In 1996, a Bongo sampler tow was also made near the halfway point between standard stations. At all standard stations, a suite of observations of the physical and biological environment of the larvae was made as part of the broad-scale sampling protocol including a hydrographic cast with a CTD and Niskin bottle rosette for sampling water at selected depths for subsequent biological and chemical analysis. The zooplankton community was sampled along with ichthyplankton during the $1 \mathrm{~m}^{2}$ MOCNESS tow using $153 \mu \mathrm{m}$ mesh nets. A plankton pumping system to sample zooplankton was also employed at some stations as well as a $10 \mathrm{~m}^{2}$ MOCNESS with $3 \mathrm{~mm}$ mesh nets to sample zooand ichthyoplankton predators and late larval stages of cod and haddock.

Bongo samplers were fitted with paired nets with digital flow meters suspended across the mouth to estimate volume filtered and were towed obliquely from the surface to $5 \mathrm{~m}$ above the bottom or to a maximum depth of $200 \mathrm{~m}$ and back to the surface, with wire payed out at $50 \mathrm{~m} \mathrm{~s}^{-1}$ and retrieved at $20 \mathrm{~m} \mathrm{~s}^{-1}$. At stations with a water depth of less than $61 \mathrm{~m}$, these rates were reduced to provide a minimum of $5 \mathrm{~min}$ tow duration. A Seabird CTD attached to the towing wire above the Bongo frame provided real-time monitoring of tow depth as well as temperature and salinity profiles during towing. Samples were rinsed with seawater in a $330 \mu \mathrm{m}$ sieve and the contents of one of the nets was preserved in $5 \%$ buffered formalin for subsequent determination of ichthyoplankton species composition, abundance and distribution. Contents of the other net were preserved in $95 \%$ ethanol for age and growth analyses of larval fish.

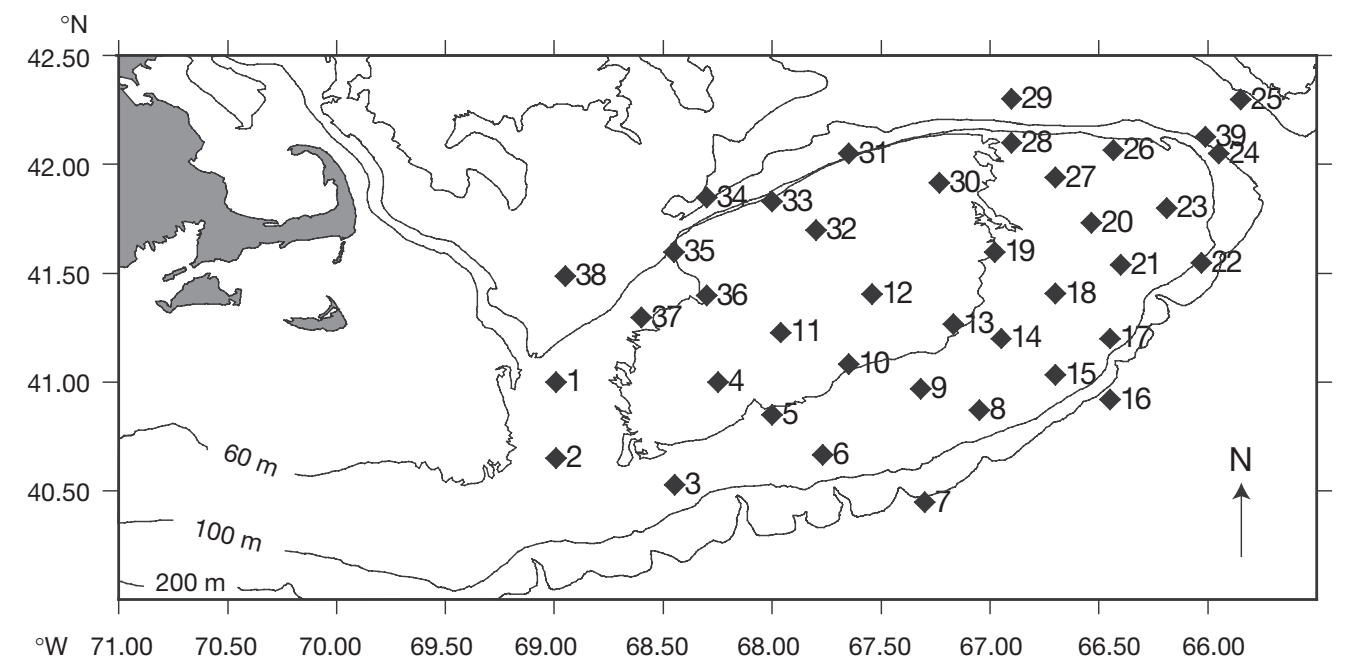

Fig. 1. Station locations for US GLOBEC Georges Bank Program broad-scale surveys for 1995 and 1996. In 1996, a Bongo net tow was added at the midpoint in the transit between consecutively numbered stations 
Of the 10 nets loaded on the $1 \mathrm{~m}^{2}$ MOCNESS, nets 6 to 9 were used to sample ichthyoplankton for age and growth studies, and nets 0 to 5 were used to sample zooplankton. The nets for sampling ichthyoplankton were fished at the following depths: $>100 \mathrm{~m}$ to nearbottom, 40-100 m, 15-40 m and 0-15 m, respectively. MOCNESS tows were double oblique with a retrieval rate of $10 \mathrm{~m} \mathrm{~min}^{-1}$ for the ichthyoplankton nets. MOCNESS samples intended for larval age and growth studies were preserved in $95 \%$ ethanol. After $24 \mathrm{~h}$ of initial preservation, the ethanol was replaced in both Bongo and MOCNESS collected samples.

Ashore, all larvae from samples were sorted and identified. Otolith microstructure (enumeration of daily growth increments) was utilized to determine larval age in days (Pannella 1971, Brothers et al. 1976), a method that has been thoroughly reviewed in Stevenson \& Campana (1992) and is commonly used for determining the ages of field-caught larvae. In most cases, ages of all the larvae from a sample were determined. In samples with a large number of larvae, up to 20 larvae of each species were analyzed from any single sample, ensuring that a representative size range was included in the subsample. Otolith preparation generally followed the techniques outlined in Secor et al. (1992) with specific details as described below. Cod and haddock were re-measured to the nearest $0.1 \mathrm{~mm}$ on a $1 \times 3$ inch slide by using a dissecting microscope. The 2 sagittae and 2 lapilli from each fish were removed under polarized light. Otoliths from fish $\leq 13 \mathrm{~mm}$ SL were coated with a thin layer of Cytoseal before rings were counted under a Zeiss Axioskop 50. The otoliths from larvae $>13 \mathrm{~mm}$ SL were embedded flat side down in thermoplastic (crystal-bond). The crystal-bonded otoliths were wet-sanded with 1500grit paper, until a readable plane on the otolith was obtained. All readings were done under bright-field illumination at $1000 \times$. Larvae age (in days, d) was determined as the number of increments counted from the hatch check to the margin of the otolith. Criteria for the hatch check were those described in Bolz \& Lough (1983). An experienced otolith reader, using laboratory reared cod and haddock larvae of known age, provided training for personnel responsible for counting increments. Results of aging based on increment counts during training were compared between readers to identify and resolve any bias. Ages for field caught larvae in this study are the mean of 6 replicate increment counts for each specimen. In their study of larval cod and haddock, Bolz \& Lough (1983) corrected for shrinkage due to preservation by using the livelength correction developed by Theilacker (1980) for northern anchovy Engraulis mordax. For purposes of comparisons between months and years of this study, no attempt was made here to correct for shrinkage. It was reasoned, as did Campana \& Hurley (1989), that the live-length correction developed by Theilacker (1980) for anchovy larvae was inappropriate for gadiform larvae. Linear and exponential growth models were selected for both species to describe and contrast growth between months and years, and for comparison with previous studies. Growth model parameters were determined using SPSS Sigma Plot.

Temperature was examined as a correlate to growth by plotting the mean of the ratio of the residual of observed size-at-age to predicted linear model size-atage $\times 100$ for each larva against integrated water column temperatures (surface to $30 \mathrm{~m}$ ) derived from CTD data. The term 'growth differential' (GD) as a percent was applied to the ratio of residual growth to predicted size. Those stations with fewer than 3 aged larvae were omitted to minimize sensitivity to small sample variability. Stations with unusually low integrated water column temperatures were found to have low salinities also. The temperature profiles at these stations were examined and it was noted that the low temperatures and salinities were restricted to the upper 10 to $15 \mathrm{~m}$, suggesting incursions of Scotian Shelf water, as described in Bisagni et al. (1996). These stations were considered non-representative of the average growing conditions for larvae on Georges Bank and larvae from these samples, which may have been advected into the area, were not included in the analysis.

\section{RESULTS}

A total of 6940 cod and haddock larvae were collected during the 1995 and 1996 field seasons. Otoliths were examined from 1791 larvae. Daily increment counts were quite reproducible between technicians with a variation between counts of $<8 \%$. Catches, and hence the number of larval otoliths available for analysis, varied substantially in each month during the field season. In some instances, otoliths extracted from larvae were unreadable, especially those from 1996. This condition was generally characteristic of all larvae in an affected sample and in some cases for most of the stations in a survey. In these cases, the larvae appeared properly preserved but the dissected otoliths were discolored to a tea-like color and opaque with no daily increments visible, in contrast to the colorless and transparent appearance of 'readable' otoliths.

Total catches of larvae and numbers used for age analysis are listed in Table 1. Mean catches by month of cod and haddock larvae in 1995 and 1996 are shown in Fig. 2. Numbers of cod (Fig. 2a) were higher in January, February and March of 1996 than in 1995, but higher in April and May of 1995; whereas, abundance 
Table 1. 1995 and 1996 cruise dates, sampling gear, station numbers, catches and size ranges of larval cod and haddock used in otolith analysis. -: otoliths could not be aged

\begin{tabular}{|c|c|c|c|c|c|c|c|}
\hline $\begin{array}{l}\text { Year } \\
\text { Cruise }\end{array}$ & Sample date & Sampling gear & $\begin{array}{c}\text { No. of } \\
\text { stations }\end{array}$ & $\begin{array}{l}\text { Total } \\
\text { cod } \\
\text { catch }\end{array}$ & $\begin{array}{c}\text { Total } \\
\text { haddock } \\
\text { catch }\end{array}$ & $\begin{array}{l}\text { Otolith aged } \\
\text { cod size } \\
\text { range }(\mathrm{mm})\end{array}$ & $\begin{array}{c}\text { Otolith aged } \\
\text { haddock size } \\
\text { range }(\mathrm{mm})\end{array}$ \\
\hline \multicolumn{8}{|l|}{1995} \\
\hline EN261 & Feb 11-19 & MOCNESS $1 \mathrm{~m}^{2}$, Bongo $61 \mathrm{~cm}$ & 37 & 97 & 13 & $2.1-7.0$ & $\begin{array}{c}4.5 \text { (only } \\
1 \text { processed) }\end{array}$ \\
\hline EN263 & Mar $14-23$ & MOCNESS $1 \mathrm{~m}^{2}$ & 38 & 764 & 168 & $1.8-15.1$ & $1.6-9.9$ \\
\hline EN265 & Apr $12-21$ & MOCNESS $1 \mathrm{~m}^{2}$ & 38 & 1287 & 416 & $2.2-17.3$ & $2.3-9.1$ \\
\hline AL9505 & May 8-19 & MOCNESS $1 \mathrm{~m}^{2}$ & 38 & 467 & 112 & $3.0-18.7$ & $3.1-17.6$ \\
\hline AL9506 & Jun $5-16$ & MOCNESS $1 \mathrm{~m}^{2}$ & 38 & 10 & 15 & $2.7-26.0$ & $2.6-22.4$ \\
\hline AL9508 & Jul 11-20 & MOCNESS $1 \mathrm{~m}^{2}$ & 38 & 8 & 3 & - & 11.3 \\
\hline \multicolumn{8}{|l|}{1996} \\
\hline EN276 & Jan 11-21 & MOCNESS $1 \mathrm{~m}^{2}$, Bongo $61 \mathrm{~cm}$ & 52 & 117 & 6 & $2.5-3.1$ & - \\
\hline EN278 & Feb $14-24$ & MOCNESS $1 \mathrm{~m}^{2}$, Bongo $61 \mathrm{~cm}$ & 68 & 380 & 83 & $2.4-10.4$ & $3.3-5.2$ \\
\hline OC275 & Mar $12-22$ & MOCNESS $1 \mathrm{~m}^{2}$, Bongo $61 \mathrm{~cm}$ & 72 & 939 & 152 & $2.0-12.3$ & $2.3-8.3$ \\
\hline EN282 & Apr 9-19 & MOCNESS $1 \mathrm{~m}^{2}$, Bongo $61 \mathrm{~cm}$ & 54 & 994 & 446 & $2.7-25.0$ & $1.7-7.8$ \\
\hline AL9605 & May $7-16$ & MOCNESS $1 \mathrm{~m}^{2}$, Bongo $61 \mathrm{~cm}$ & 66 & 328 & 100 & $5.2-35.0$ & - \\
\hline AL9607 & Jun $4-12$ & MOCNESS $1 \mathrm{~m}^{2}$, Bongo $61 \mathrm{~cm}$ & 41 & 22 & 13 & $12.2-16.4$ & - \\
\hline
\end{tabular}

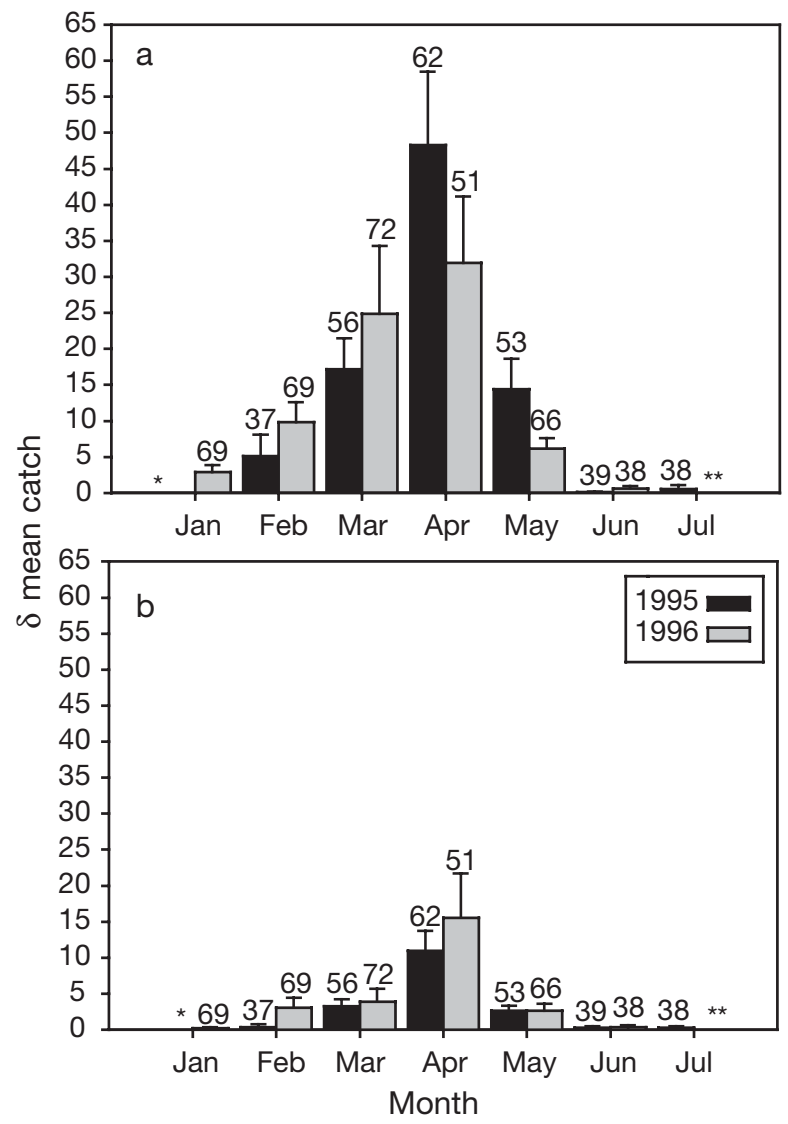

Fig. 2. Gadus morhua and Melanogrammus aeglefinus. $\delta$ mean catch $(+\mathrm{SE})$ of (a) cod and (b) haddock larvae per $10 \mathrm{~m}^{2}$ tow ${ }^{-1}$ based on $61 \mathrm{~cm}$ Bongo net sampling for monthly GLOBEC Broad-scale Surveys, 1995, 1996. Number of stations sampled are indicated above each column. *: no Jan sampling in 1995. **: no July sampling in 1996 of haddock was greater in February, March and April of 1996 than in 1995. In May and June, numbers of haddock were similar in both years. In general, the largest numbers of cod were taken in March and April corresponding to the time of peak spawning (Sherman et al. 1984). Recently hatched cod (1.8 to $3.0 \mathrm{~mm}$ ) were available for otolith examination from February to June in 1995, and from January to April in 1996 (Table 1). Haddock were taken in greatest numbers in April. However, recently hatched larvae (1.6 to $3.3 \mathrm{~mm}$ ) were available for otolith examination in all months sampled through June in 1995 and February through April in 1996. The maximum size taken increased as the season progressed. The catches of cod were distributed over a broader span of time than haddock, which show a peak of production of larvae in April, with many fewer taken in February/March and May/June. Cod was approximately 4 times more abundant than haddock in both years.

The majority of cod larvae available for otolith analysis were <50 d old in all surveys prior to May of both years (Fig. 3). By May, larvae up to 2 mo old were reasonably abundant but individuals in excess of $70 \mathrm{~d}$ old were not taken. This is in contrast to the results reported by Bolz \& Lough (1988) and Campana \& Hurley (1989), where specimens of age $90 \mathrm{~d}$ and older were taken in May. On the whole, fewer haddock were available for aging and the data provide a less coherent picture of growth than for cod (Fig. 4). Sufficient numbers of haddock to calculate age-length relationships were taken in March through May in 1995. Only individuals at the extremes of the size range were available from June sampling. In February 1996, had- 
dock were $<20 \mathrm{~d}$ old and $<7.0 \mathrm{~mm}$ SL. Similarly, in March 1996, haddock were mostly recently hatched and small with only a few fish more than a month old. In April 1996, a broader range of ages was found with fish from newly hatched ( 3 to $4 \mathrm{~d}$ old) to some specimens approximately 2 mo old.

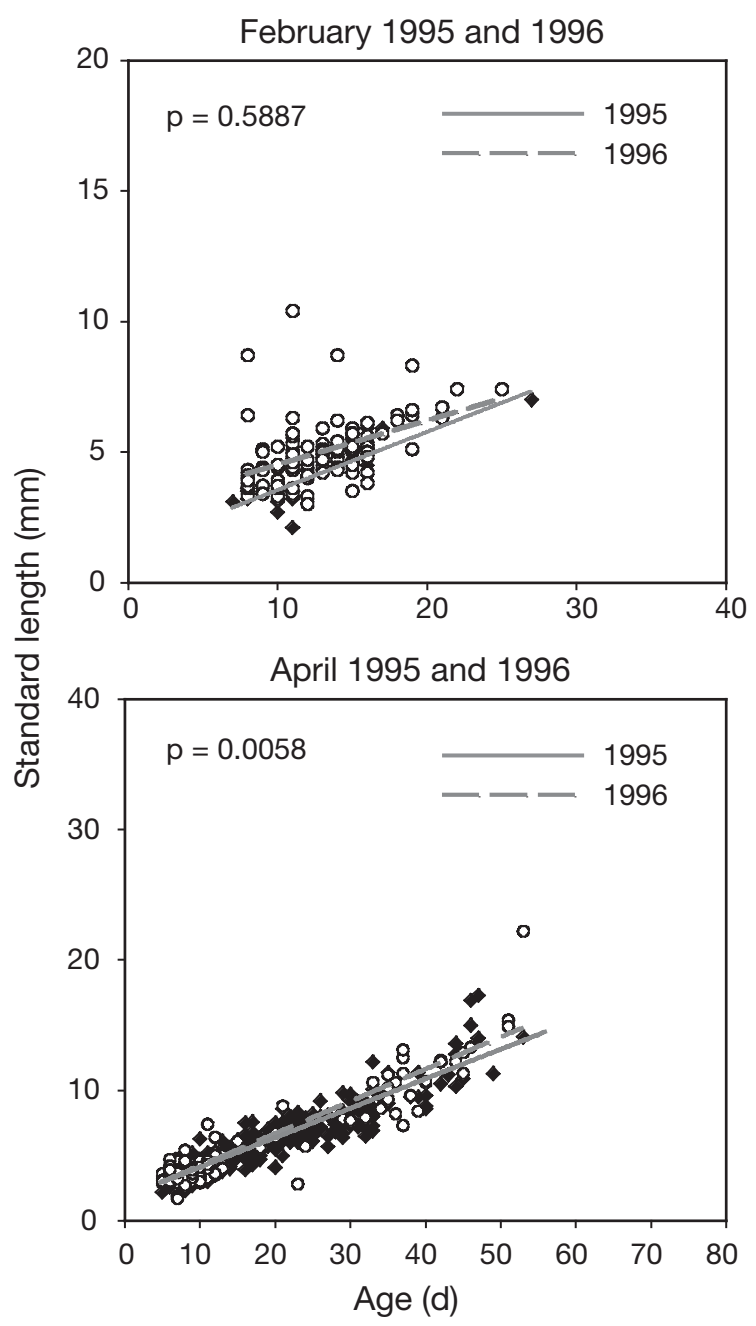

\section{Growth of larvae in 1995 and 1996}

Of the growth models fitted to the data, the best fits were achieved with exponential and simple linear growth models of length against age, with coefficients of determination $\left(R^{2}\right)$ generally greater than 0.8
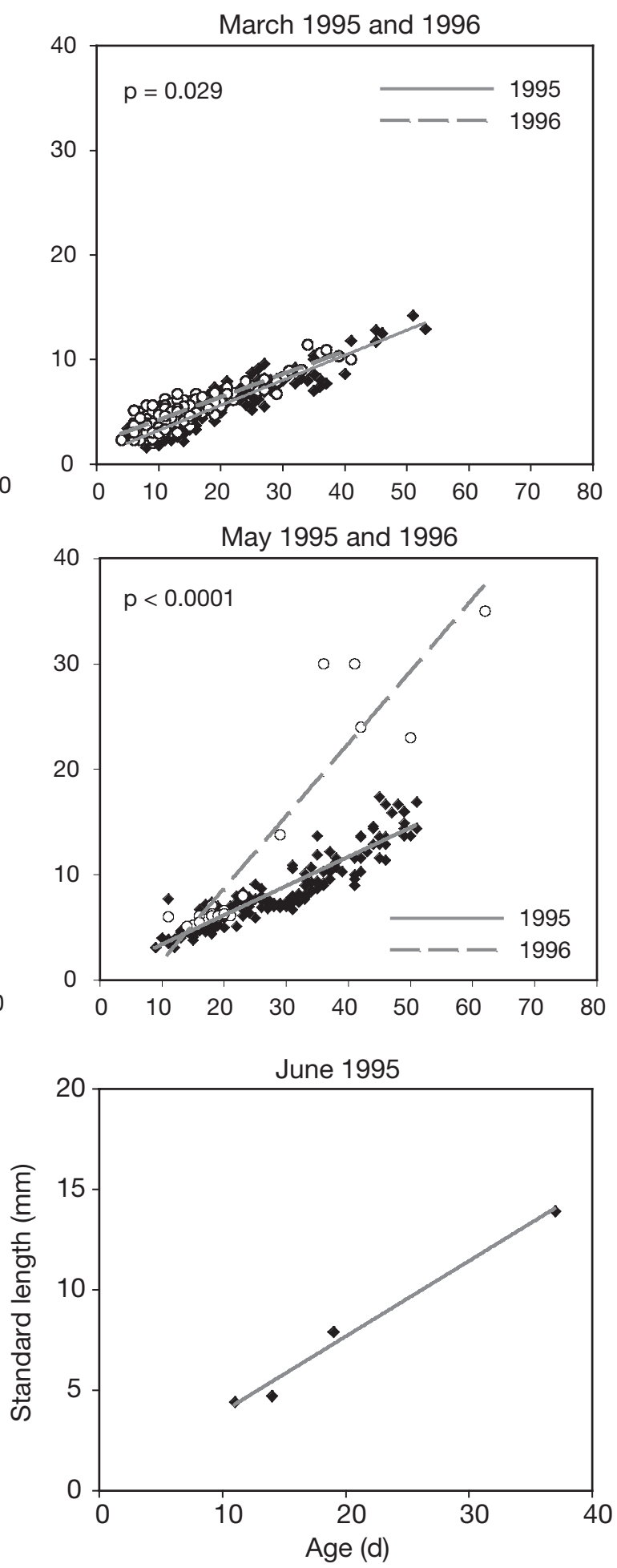

Fig. 3. Gadus morhua. Age and growth of cod larvae February-June 1995 and February-May 1996. Age is days post-hatching as indicated by otolith increment count. Standard length $(\mathrm{mm})$ was measured on preserved specimens at the time of otolith dissection. $p$ values for each month are for comparison of slopes between years. Equations for regression models are given in Table $2 . \bullet=1995$ data, $\circ=1996$ data 

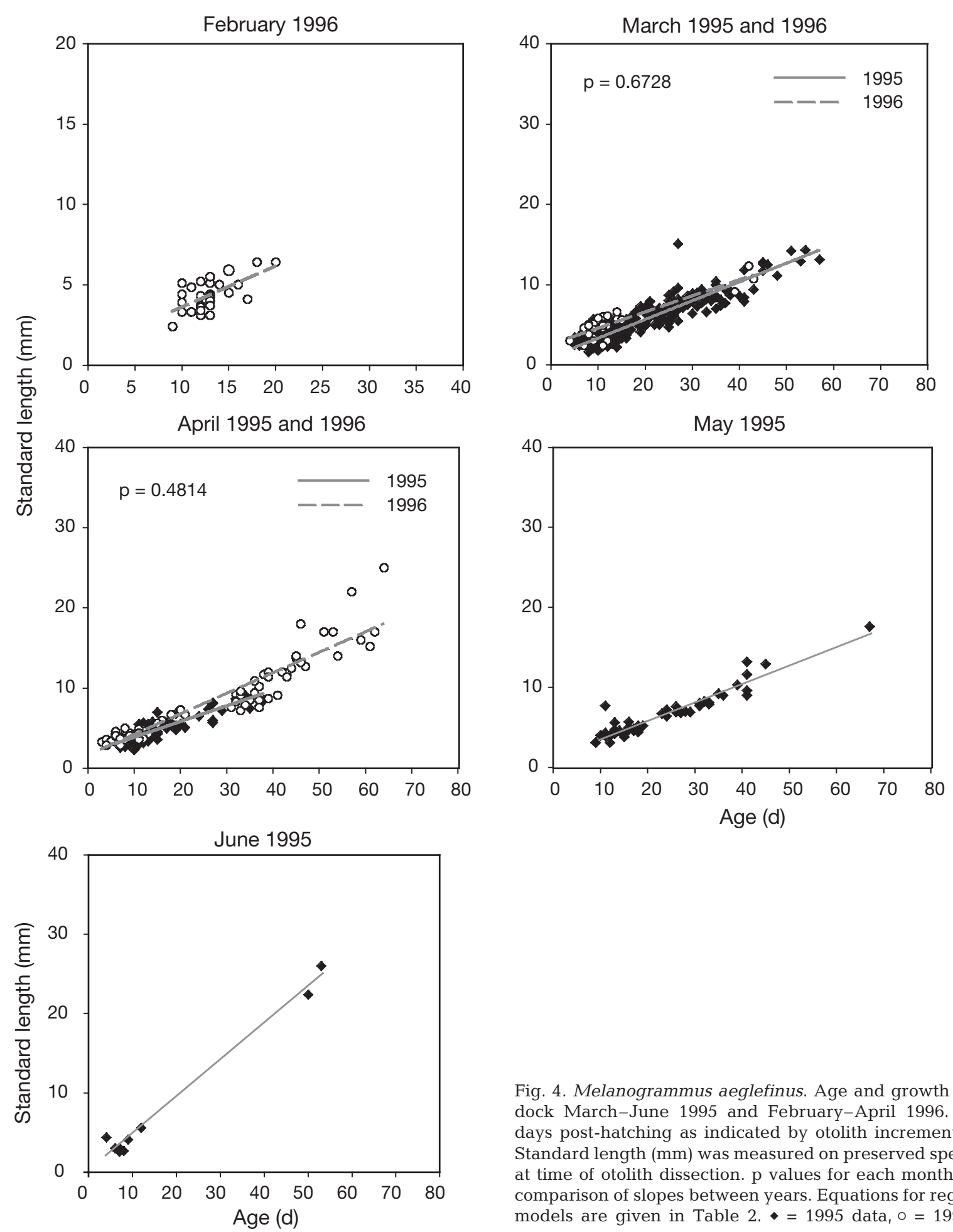

(Table 2). In general, the linear model fit was slightly better than the exponential fit and was used for comparisons by month between years. Both linear and exponential growth regressions were significant and in most cases, $\mathrm{p}<0.001$ for both species with the exception of

Fig. 4. Melanogrammus aeglefinus. Age and growth of haddock March-June 1995 and February-April 1996. Age is days post-hatching as indicated by otolith increment count. Standard length $(\mathrm{mm})$ was measured on preserved specimens at time of otolith dissection. $p$ values for each month are for comparison of slopes between years. Equations for regression models are given in Table $2 . \bullet 1995$ data, $\circ=1996$ data

that for cod in January 1996. In general, the age-length relationships determined for each month reflect the predominance of young larvae (Figs. $3 \& 4$ ). The fits of the age-length relationship were slightly better with linear models (Table 2). 
Table 2. Gadus morhua and Melanogrammus aeglefinus. Statistics for larval cod and haddock growth models in 1995 and 1996. -: no data due to small sample size

\begin{tabular}{|c|c|c|c|c|c|c|c|c|c|c|c|c|}
\hline \multirow{3}{*}{$\begin{array}{l}\text { Year } \\
\text { Sample date } \\
\text { (Cruise) }\end{array}$} & \multirow[t]{3}{*}{ Species } & \multirow[t]{3}{*}{$\mathrm{N}$} & \multicolumn{5}{|c|}{ Linear model parameters $\left(y=y_{0}+a x\right)$} & \multicolumn{5}{|c|}{ Exponential growth model parameters $\left(y=a \mathrm{e}^{b x}\right)$} \\
\hline & & & \multicolumn{2}{|c|}{ Slope (a) } & \multicolumn{2}{|c|}{ Intercept $\left(y_{0}\right)$} & \multirow[b]{2}{*}{$\mathrm{R}^{2}$} & \multicolumn{2}{|c|}{ Slope $(b)$} & \multicolumn{2}{|c|}{ Intercept $(a)$} & \multirow[b]{2}{*}{$\mathrm{R}^{2}$} \\
\hline & & & Estimated & SE & Estimated & SE & & Estimated & $\mathrm{SE}$ & Estimated & SE & \\
\hline \multicolumn{13}{|l|}{1995} \\
\hline Feb 11-19 & Cod & 17 & 0.2230 & 0.0322 & 1.2615 & 0.4097 & 0.7502 & 0.0447 & 0.0059 & 2.2450 & 0.2140 & 0.7104 \\
\hline$(\mathrm{EN261})$ & Haddock & 1 & - & - & - & - & - & - & - & - & - & - \\
\hline Mar 14-23 & Cod & 389 & 0.2395 & 0.0050 & 0.7484 & 0.0811 & 0.8566 & 0.0370 & 0.0007 & 2.3652 & 0.0440 & 0.8129 \\
\hline (EN263) & Haddock & 105 & 0.2262 & 0.0138 & 0.6953 & 0.1962 & 0.7250 & 0.0429 & 0.0022 & 1.9987 & 0.0921 & 0.7103 \\
\hline Apr 12-21 & Cod & 285 & 0.2261 & 0.0059 & 1.7101 & 0.1306 & 0.8401 & 0.0307 & 0.0007 & 3.2111 & 0.0719 & 0.8348 \\
\hline (EN265) & Haddock & 107 & 0.1954 & 0.0099 & 1.8073 & 0.1514 & 0.7886 & 0.0336 & 0.0016 & 2.7629 & 0.0909 & 0.7540 \\
\hline May 8-19 & Cod & 142 & 0.3017 & 0.0112 & 0.0701 & 0.4046 & 0.8391 & 0.0293 & 0.0010 & 3.5310 & 0.1432 & 0.8457 \\
\hline (AL9505) & Haddock & 49 & 0.2296 & 0.0113 & 1.2265 & 0.2969 & 0.8996 & 0.0263 & 0.0012 & 3.3868 & 0.1596 & 0.8812 \\
\hline Jun 5-16 & Cod & 4 & 0.3758 & 0.0334 & 0.1141 & 0.7567 & 0.9844 & 0.0412 & 0.0060 & 3.0607 & 0.5772 & 0.9621 \\
\hline (AL9506) & Haddock & 9 & 0.4659 & 0.022 & 0.1351 & 0.5569 & 0.9846 & 0.0433 & 0.0022 & 2.6054 & 0.2811 & 0.9918 \\
\hline Jul 11-20 & Cod & 0 & - & - & - & - & - & - & - & - & - & - \\
\hline (AL9508) & Haddock & 1 & - & - & - & - & - & - & - & - & - & - \\
\hline \multicolumn{13}{|l|}{1996} \\
\hline Jan $11-21$ & Cod & 7 & 0.0063 & 0.0961 & 2.7000 & 0.8841 & 0.0008 & - & - & _- & - & - \\
\hline (EN276) & Haddock & 0 & - & - & - & - & - & - & - & - & - & - \\
\hline Feb $14-24$ & Cod & 115 & 0.1691 & 0.0300 & 2.7581 & 0.4016 & 0.2200 & 0.0339 & 0.0055 & 3.1685 & 0.2463 & 0.2303 \\
\hline (EN278) & Haddock & 29 & 0.2552 & 0.0602 & 1.0278 & 0.7906 & 0.3994 & 0.0556 & 0.0120 & 2.0875 & 0.3483 & 0.4064 \\
\hline Mar 12-22 & Cod & 207 & 0.2189 & 0.0088 & 1.9255 & 0.1251 & 0.7491 & 0.0345 & 0.0012 & 2.9566 & 0.0702 & 0.7298 \\
\hline (OC275) & Haddock & 32 & 0.2011 & 0.0186 & 2.4987 & 0.2960 & 0.7954 & 0.0281 & 0.0022 & 3.3918 & 0.1973 & 0.7854 \\
\hline Apr 09-19 & Cod & 171 & 0.2467 & 0.0073 & 1.5817 & 0.1343 & 0.8703 & 0.0345 & 0.0008 & 2.8294 & 0.0731 & 0.8993 \\
\hline (EN282) & Haddock & 76 & 0.2555 & 0.0107 & 1.5486 & 0.3402 & 0.8845 & 0.0293 & 0.0011 & 3.3397 & 0.1773 & 0.9130 \\
\hline May 07-16 & Cod & 20 & 0.6861 & 0.0621 & -5.2544 & 1.7778 & 0.8714 & 0.0352 & 0.0044 & 4.4916 & 0.9351 & 0.7690 \\
\hline (AL9605) & Haddock & 0 & - & - & - & - & - & - & - & - & - & - \\
\hline Jun $04-12$ & Cod & 2 & - & - & - & - & - & - & - & - & - & - \\
\hline (AL9607) & Haddock & 0 & - & - & - & - & - & - & - & - & - & - \\
\hline
\end{tabular}
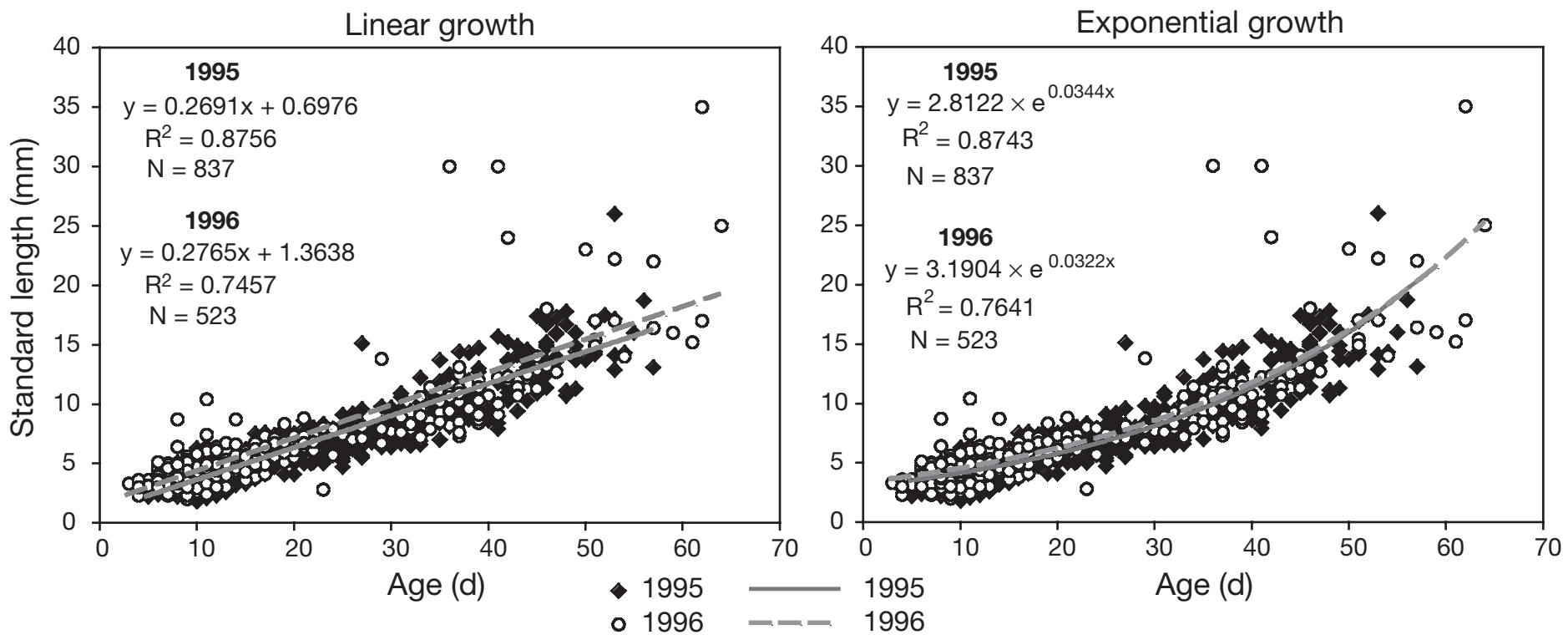

Fig. 5. Gadus morhua. Exponential and linear models of larval cod growth for all sampled months combined in 1995 and 1996 

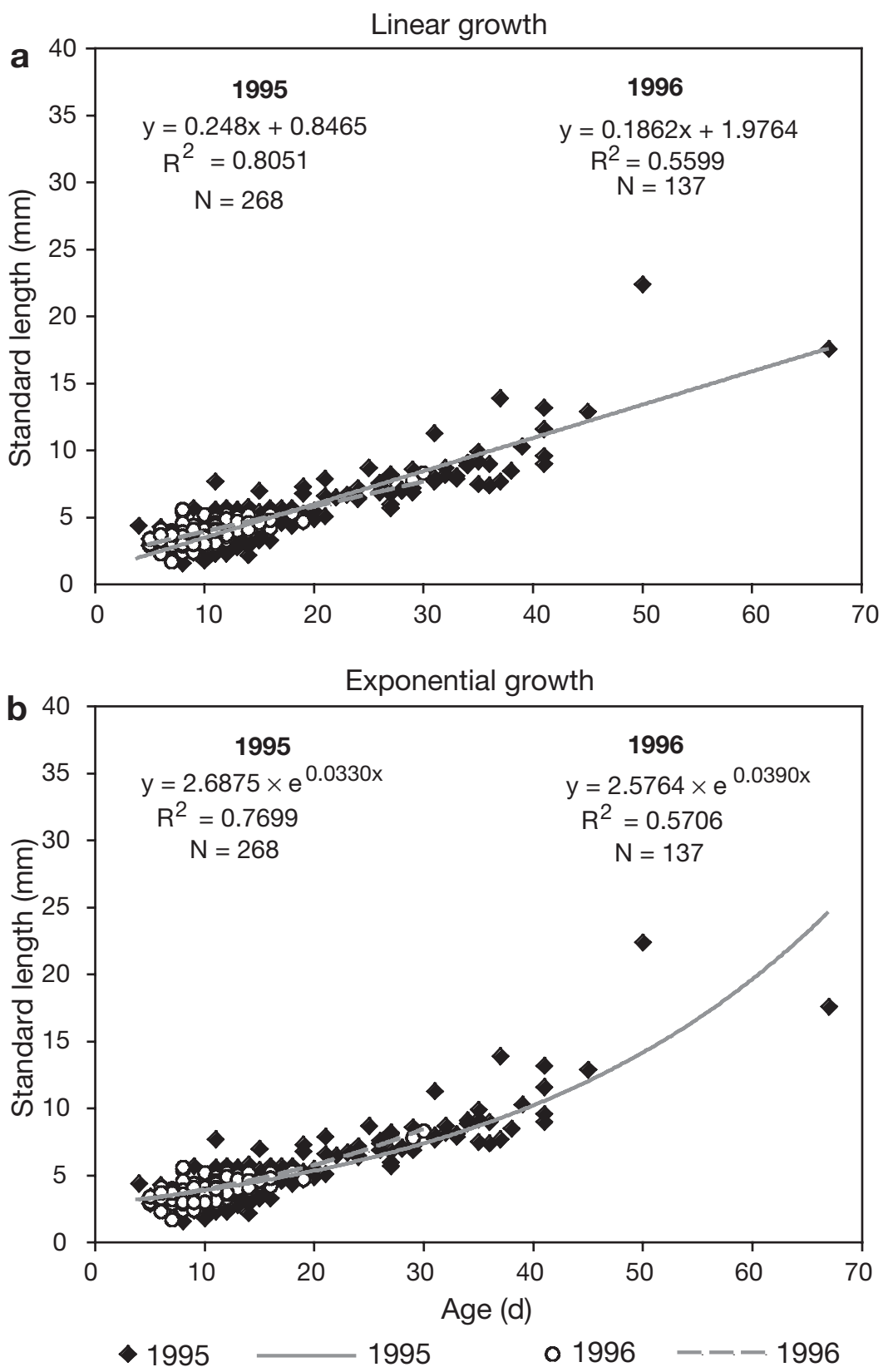

Fig. 6. Melanogrammus aeglefinus. (a) Exponential and (b) linear models of larval haddock growth for all sampled months combined in 1995 and 1996

In general, growth of larval cod exceeded $0.2 \mathrm{~mm}$ $\mathrm{d}^{-1}$. Growth rates (slopes of the derived age-length relationships) for February, March, April and May of 1995, and 1996 are shown in Fig. 3 \& Table 2. Differences in growth rate of cod between the 2 yr were significant (ANCOVA, p < 0.05) for March, April and May, but not significant for February. Growth was greater in March 1995 than in March 1996, but daily growth in April and May was greater in 1996. Haddock growth rates were not significantly different between years in
March and April. The monthly age-length relationships are based on the abundant younger fish, which form a cluster of data points near the origin, and relatively few larger fish which tends to determine the slope of the line and hence, the predicted intercept. Predicted lengths at hatching as derived from the $y$-intercept were highly variable and low (<2.6 mm, Table 2$)$.

The age-length relationships for all months combined in 1995 and 1996 calculated to characterize growth during the entire sampling period for each year are shown in Figs. 5 \& 6. For cod (Fig. 5), the data show an increase in variability in size with age, especially in 1996. Both exponential and linear model regressions were significant $(p<0.0001)$ with a slightly higher $\mathrm{R}^{2}$ found with a linear growth model in 1995, but with the exponential model in 1996; the latter reflecting the wider range of sizes-at-age found in the May 1996 samples. In 1995, only 2 haddock were older than $45 \mathrm{~d}$ (Fig. 6). As with cod in 1995, growth again appears to be slightly better described by a linear agelength relationship. In 1996, virtually all the ages obtained for haddock were from fish younger than $20 \mathrm{~d}$ and the variability associated with fish in that age range was similar to the variability observed in 1995.

The data from individual months during the sampling period show considerable variability and significant differences between the 2 yr (Fig. 3). Cod larvae were growing at 0.22 to $0.38 \mathrm{~mm} \mathrm{~d}^{-1}$ between February and June 1995, and at 0.17 to $0.69 \mathrm{~mm} \mathrm{~d}^{-1}$ in 1996 (Table 2). With few exceptions, larvae examined were $<60 \mathrm{~d}$ old. Bolz \& Lough (1983) reported 0.18 and $0.28 \mathrm{~mm} \mathrm{~d}^{-1}$, for the first and second months of life for cod larvae captured late in the larval period in April and May 1981. Growth appeared to be consistently higher from February to May 1995 than in 1996 and more variable in 1996 (including relatively slow growth rates early in February of 1996, but substantially faster growth by May). Growth as change in length $\mathrm{d}^{-1}$ increased in each succeeding month of the larval phase in both years.

In general, larval haddock growth rates showed considerable variability among months (for which readable otoliths were available) and between the $2 \mathrm{yr}$. Haddock growth rates were determined for March to June of 1995 and for February to April of 1996. As with 


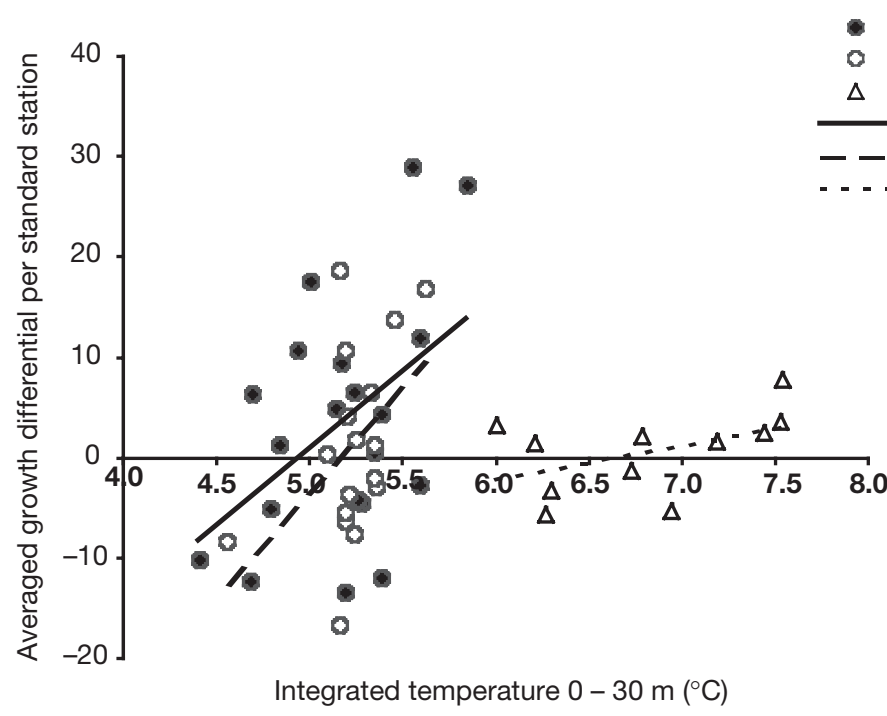

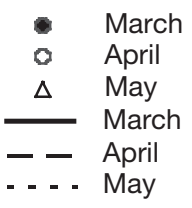

$$
\begin{gathered}
\text { March 1995 } \\
y=15.299 x-75.882 \\
R^{2}=0.2091 \\
N=20
\end{gathered}
$$

April 1995

$y=20.393 x-105.51$

$R^{2}=0.2092$

$\mathrm{N}=18$

May 1995

$y=3.4772 x-23.104$

$\mathrm{R}^{2}=0.2274$

$\mathrm{N}=11$ cod, growth estimates were largely from larvae $<60 \mathrm{~d}$ old. The growth rates of haddock were 0.20 to $0.26 \mathrm{~mm}$ $\mathrm{d}^{-1}$ through May of both years (Table 2). Growth rates calculated for June of 1995 are considerably higher $\left(0.46 \mathrm{~mm} \mathrm{~d}^{-1}\right)$ but ages were determined for only 9 larvae taken from 6 stations. In 1996, no haddock ages were obtained in May or June. Specific growth ranged from a low of 0.026 in May 1995 to a high of 0.056 in February 1996. The elevated specific growth observed in February 1996 was confined to larvae aged 9 to $20 \mathrm{~d}$ and the fit of both linear and exponential growth models to the data although significant is poor $\left(R^{2}=0.4\right)$. A high specific growth $(0.043)$ was observed for haddock in June of 1995.

Plots of integrated temperature versus averaged growth differential (GD) are shown in Figs. $7 \&$ \& . A least squares linear fit was calculated to indicate trends in the data. A highly variable but consistent relationship exists between larger size-at-age and higher temperatures for cod in March, April and May of 1995 (Fig. 7). In March of 1995, stations with > 3 cod larvae were in 4.4 to $5.8^{\circ} \mathrm{C}$ water. The apparent trend was for larger larvae to have been taken from warmer water. Although the range of temperatures is similar to that in March, by April most of the cod larvae examined were taken in water of $>5^{\circ} \mathrm{C}$. Again, there was a positive trend in the growth differential with increasing temperature. In May, the growth differential trend associated with temperature remained positive, but the slope of the trend had diminished with temperatures at 6 to $7.5^{\circ} \mathrm{C}$.

Haddock showed a similar response to temperature in 1995 (Fig. 8). The earliest hatched larvae in March were larger at the stations with higher temperatures.

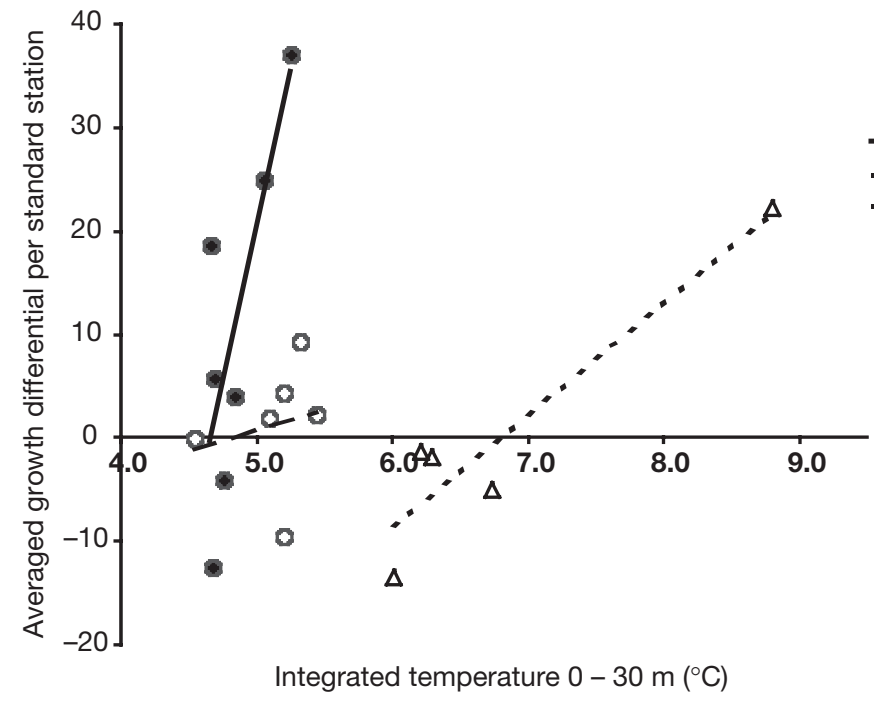

Integrated temperature $0-30 \mathrm{~m}\left({ }^{\circ} \mathrm{C}\right)$

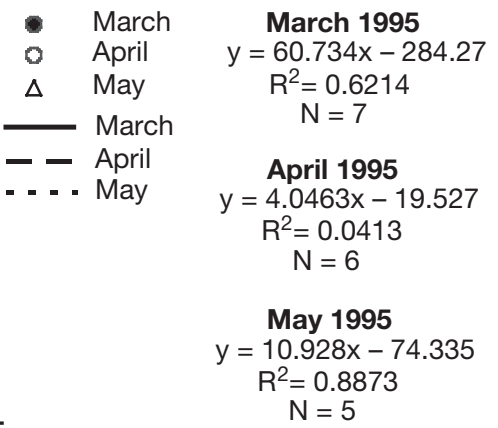

Fig. 8. Melanogrammus aeglefinus. Relationship of larval haddock growth differential to integrated water column temperature $(0-30 \mathrm{~m})$ by month in 1995. Growth differential is the ratio of the observed size-at-age to predicted size-at-age $\times 100$ 
Most of the larvae were taken in water that was $5^{\circ} \mathrm{C}$ or less. By April, there was less of a trend in the correlation of growth rate with temperature for haddock, with most of the larvae occurring at 5.1 to $5.5^{\circ} \mathrm{C}$. Data for haddock in May are rather sparse with only 5 stations having more than 3 larvae but again, increased size is correlated with higher temperature.

There were only 2 stations in May of 1996 with data for more than 3 cod larvae and stations with $>3$ haddock larvae were few throughout the 1996 sampling period. Early in the year during February to April, water column temperatures remained lower than in 1995 with a range of $<1.5^{\circ} \mathrm{C}$ from the lowest temperatures in February $\left(4.2^{\circ} \mathrm{C}\right)$ to the highest in April $\left(5.4^{\circ} \mathrm{C}\right)$, and water temperatures only began to show seasonal warming similar to 1995 in May. No consistent relationship between temperature and growth from February to March was evident over the narrow range of temperatures in 1996.

\section{DISCUSSION}

\section{Comparison with previous studies}

A limitation of describing growth on the basis of field data is a lack of control over observations at critical times in larval development. In this study, as well as in Bolz \& Lough (1983) and Campana \& Hurley (1989), data on larval cod and haddock younger than 3 to $5 \mathrm{~d}$ are not represented in the growth curves. Growth curves based on otolith increments presented by Jeffrey \& Taggart (2000) for another gadid species, Merluccius bilinearis, also do not represent larvae younger than $3 \mathrm{~d}$. A possible explanation for the absence of larvae with otoliths with 1 to 2 increments may be that ring deposition actually occurs with physiological changes that take place prior to hatching and larvae may emerge with 1 to 2 daily increments. However, laboratory studies on cod (Ratke 1989) and haddock (Quinonez-Velasquez 1999) have validated daily ring formation that begins on the first day after hatching. Another possibility is that larvae younger than $3 \mathrm{~d}$ are actually not taken in samples, but rather having relatively soft tissues upon emergence from the egg, are extruded during the sampling tow. The latter would appear the more likely because significant extrusion depending on mesh size and tow duration has been shown for other species, including jack mackerel (Hewitt et al. 1985) and bay anchovy (Leak \& Houde 1987). Rilling \& Houde (1999) adjusted abundances of larvae by factors of 1.9 to 1.6 for larvae of 3.0 to $4.0 \mathrm{~mm}$ SL respectively, taken in $5 \mathrm{~min}$ tows with $280 \mu \mathrm{m}$ mesh nets. As indicated above, mesh size in this study was $335 \mu \mathrm{m}$ and tow times, although variable depending on depth, were longer, typically $30 \mathrm{~min}$ in this study. Similar sampling gear was employed in the studies of cod, haddock and silver hake noted above and tow times, although not described in detail, are likely to have been similar to this study given the areas sampled. Lacking data from hatching larvae, Bolz \& Lough (1983) used the $y$-intercept (age $=0$ ) to estimate hatch length (4.8 and $3.5 \mathrm{~mm}$ for cod and haddock, respectively) based on live-length corrected data from 2 cruises in 1981, and noted that the projected size at age 0 agreed with the upper range of size at hatch given in Colton \& Marak (1969). Using the exponential growth model used by Bolz \& Lough (1983) for data in this study with samples combined in each year, the $y$-intercept for cod at 2.8 and $3.2 \mathrm{~mm}$, and haddock at 2.7 and 2. $6 \mathrm{~mm}$ for 1995 and 1996 respectively, are lower than those observed by Bolz \& Lough (1983). They are, however, similar to the minimum formalinpreserved lengths reported in Colton \& Marak (1969), of 3.3 and $3.1 \mathrm{~mm}$ for cod and haddock respectively, considering that the latter reported on total lengths rather than standard length at hatching and that the difficulty of measuring the more contorted shape of ETOH preserved larvae would tend to reduce measured lengths. Calculation of growth rates using the exponential model of Bolz \& Lough (1983) with livelength corrected data for cod larvae from this study resulted in an increase in the $y$-intercept by $0.8 \mathrm{~mm}$ to 3.6 and $4.0 \mathrm{~mm}$ for 1995 and 1996, lower than in Bolz \& Lough (1983), and a slight decrease in the specific growth rate by 0.002 for both years. Thus, correction to live-length from preserved length increases the $y$-intercept of the exponential model but has an insignificant effect on the calculated growth rate.

Growth rates of cod and haddock larvae on Georges Bank are not consistent throughout the larval period, vary between years and generally exceed those reported for laboratory-reared larvae. Bolz \& Lough (1988) combined data from 1981, 1983 and 1984 to describe growth over the first 6 mo for cod and haddock larvae caught late in the larval period in April through September. In combining data from several cruises, they provide a general description of cod and haddock growth on Georges Bank that integrates temporally over several years. Their data for cod, taken in April and May during the first $60 \mathrm{~d}$ post-hatching, indicate an average growth rate of $0.31 \mathrm{~mm} \mathrm{~d}^{-1}$ that is slightly greater than growth rates calculated for larvae caught in April and May 1995 of 0.22 and $0.30 \mathrm{~mm} \mathrm{~d}^{-1}$, respectively (Table 2). In 1996, the April growth rates were similar to 1995 (0.23 $\mathrm{mm} \mathrm{d}^{-1}$ ) but in May, growth was more than twice that in Bolz \& Lough (1988) at $0.69 \mathrm{~mm} \mathrm{~d}^{-1}$. In using only April and May data to characterize growth over an entire season, they were not able to account for the period of highest larval cod pro- 
duction but of lower temperature in March (Fig. 2). Growth rates from the linear growth model $(0.17$ to $\left.0.69 \mathrm{~mm} \mathrm{~d}^{-1}\right)$, as well as specific growth rates from this study ( 0.029 to 0.035 based on an exponential growth model) are greater than those reported by Geffen (1995) for tank-reared larvae of cod $(0.17$ and $0.23 \mathrm{~mm}$ $\mathrm{d}^{-1}$ and a specific growth of .014) for experiments of $40 \mathrm{~d}$ duration in 200 and $1000 \mathrm{l}$ tanks; and greater than those reported by Laurence et al. (1981) (at a maximum specific growth rate of $2 \% \mathrm{~d}^{-1}$ at prey densities of $3.0 \mathrm{ml}^{-1}$ in a study of competition between cod and haddock larvae reared at $7.0^{\circ} \mathrm{C}$ ).

The combined data for each year for cod, February to June 1995 and January to May 1996 (Fig. 5), indicate a somewhat lower growth rate of 0.26 to $0.27 \mathrm{~mm} \mathrm{~d}^{-1}$ for both year classes than seen by Bolz \& Lough (1988) at $0.31 \mathrm{~mm} \mathrm{~d}^{-1}$ for data combined over $3 \mathrm{yr}$ beginning in April and including larvae up to $60 \mathrm{~d}$ old. Using larvae from 1981, Bolz \& Lough (1983) found a growth rate of $0.28 \mathrm{~mm} \mathrm{~d}^{-1}$ for the first $60 \mathrm{~d}$. The wider scatter in 1996 is generally due to high growth rates seen in May as noted above. The linear growth rates seen in this study reflect growth rates measured during the entire larval period including the colder temperatures that occurred in the early months of development and are more representative of conditions for the whole season, while those reported by Bolz \& Lough (1988) represent growth in April and May after the annual temperature minimum. The overall instantaneous growth as percent increase $\mathrm{d}^{-1}$ for cod, 3.3 to $3.5 \% \mathrm{~d}^{-1}$, for 1995 and 1996 , respectively, is greater than the mean growth of $2.6 \% \mathrm{~d}^{-1}$ reported by Bolz \& Lough (1983) for larval growth.

Haddock growth rates are not as readily compared with previous studies. The maximum age obtained for 1995 haddock was 65 d, while the maximum for 1996 was $30 \mathrm{~d}$ with the majority of specimens at less than 20 d of age. Bolz \& Lough (1983) observed a specific growth of 0.035 for larvae sampled in May 1981 on Georges Bank for larvae up to $36 \mathrm{~d}$ old, which exceeds that of 0.026 observed in this study in May 1995 (Table 2). The linear growth rate derived for all months combined of 1995 (Fig. 6) at $0.25 \mathrm{~mm} \mathrm{~d}^{-1}$ is essentially equal to that for cod in 1995, slightly greater than reported by Bolz \& Lough (1983) at $0.21 \mathrm{~mm} \mathrm{~d}^{-1}$ for the first $30 \mathrm{~d}$ post hatching, but similar to $0.24 \mathrm{~mm} \mathrm{~d}^{-1}$ reported in Bolz \& Lough (1988) using different modeling techniques. They and Laurence (1978) suggest that haddock growth rates are higher than those of cod. The instantaneous growth rates found here, 3.4 to $4.0 \% \mathrm{~d}^{-1}$ for 1995 and 1996, respectively, appear consistent with their results. Bolz \& Lough (1983) note that the peak of haddock spawning generally occurs later at higher temperatures than cod spawning and suggested that cod growth at higher temperatures may be similar to that of haddock. In this study, peak spawning times of both species generally coincided (Fig. 2) resulting in a similar mean hatch date for both species. This suggests that the observed faster growth of haddock may be due to the time at which the majority of the larvae were captured. In 1995, when the majority of the larvae used to develop the growth curves for both species were taken in March and April (Table 2), the difference in growth between $\operatorname{cod}\left(3.3 \% \mathrm{~d}^{-1}\right)$ and haddock $\left(3.4 \% \mathrm{~d}^{-1}\right)$ is insignificant. In 1996, when cod larvae were growing at $3.5 \% \mathrm{~d}^{-1}$, water temperatures remained up to a degree cooler through March (when the greatest numbers of cod were captured), while the greatest numbers of haddock (growing at $4.0 \% \mathrm{~d}^{-1}$ ), were sampled in April.

\section{Effect of temperature on monthly growth estimates}

The range in size-at-age of both species may reflect varying environmental conditions during the larval period as noted above. Temperature has been shown to be critical to metabolic rate and therefore, a determinant of fish growth rate (Brett 1979). Laurence (1978) conducted laboratory studies of larval cod and haddock that examined growth over the range of 4 to $10^{\circ} \mathrm{C}$. Ratke (1989) considered age and growth in detail over a range of 6 to $10^{\circ} \mathrm{C}$ and Otterlei et al. (1999) conducted an in-depth study of temperature and size-dependent growth for larvae of Norwegian coastal and northeast Arctic cod at 4 to $14^{\circ} \mathrm{C}$. These studies demonstrated that, given adequate food levels, larval growth rate was positively correlated with temperature.

From the 1995 data, it appears that higher temperatures favor higher growth rates for cod and haddock early in the larval period in March and April on Georges Bank, but the temperature effect diminished for cod and to a lesser extent for haddock as temperature rose (Fig. 7). Although the response of haddock (Fig. 8) should be viewed with caution due to the low numbers of larvae, these results are consistent with those reported in the literature. Laurence (1978) noted that haddock grew at $13.36 \% \mathrm{~d}^{-1}$ in weight at $9^{\circ} \mathrm{C}$, while cod grew at $8.75 \% \mathrm{~d}^{-1}$ in weight at $10^{\circ} \mathrm{C}$ in laboratory studies where larvae were provided with optimum food levels. Using field data, Campana \& Hurley (1989) described a parabolic interaction of temperature with growth for cod and haddock from the Georges Bank-Scotian Shelf region. They calculated optimal temperatures for growth of 5.9 and $6.7^{\circ} \mathrm{C}$ for cod and haddock, respectively. These optimal temperatures correspond reasonably well to the temperatures at which the slopes of growth differentials measured in this study (Figs. $7 \&$ 8) show the greatest change. Buck- 
ley et al. (2004) observed similar responses by using field caught larvae and measuring RNA/DNA as an indicator of recent growth conditions. Data from their studies in 1992 to 1994 demonstrate a change in the relationship between growth rate per day and temperature, with growth increasing with temperature over a range of 5 to $7^{\circ} \mathrm{C}$ but slower growth at 7 to $10^{\circ} \mathrm{C}$. They argue that, although larval growth responds positively to increased temperature in the laboratory, it is likely that limits to food availability in the field prevent ingestion rates that would support higher growth rates predicted at temperatures greater than $7^{\circ} \mathrm{C}$ on Georges Bank.

\section{Temperature and food availability}

The timing and variability of larval production and growth has been shown to be synchronized with the production cycle of suitable prey (Sherman et al. 1984, Cushing 1990,). The normalized abundance by month of cod from bongo sampling ranged from less than 5 per $10 \mathrm{~m}^{2}$ early and late in the spawning season in January and June, to more than 30 per $10 \mathrm{~m}^{2}$ in April of 1995 (Fig. 2). In 1996, the mean abundance of cod larvae was substantially lower in April and May than in March, by about 38 and $50 \%$, respectively. During the same sequence of GLOBEC surveys in 1995 and 1996, Durbin et al. (2000) estimated the abundance of Calanus finmarchicus and examined the temporal and spatial abundance of developmental stages. Their findings indicate that total abundance of copepodites was greater in April and May of 1996 than in 1995 ( $p<0.05$ and $\mathrm{p}<0.005$ ) and in particular, the number of earlier stage ( $\mathrm{C} 1$ to 3$)$ copepodites was greater $(\mathrm{p}<0.005)$ in 1996. According to their study, winter temperatures at the seasonal minimum in March, which were around 1 degree lower in 1996 (Fig. 9), delayed the time of

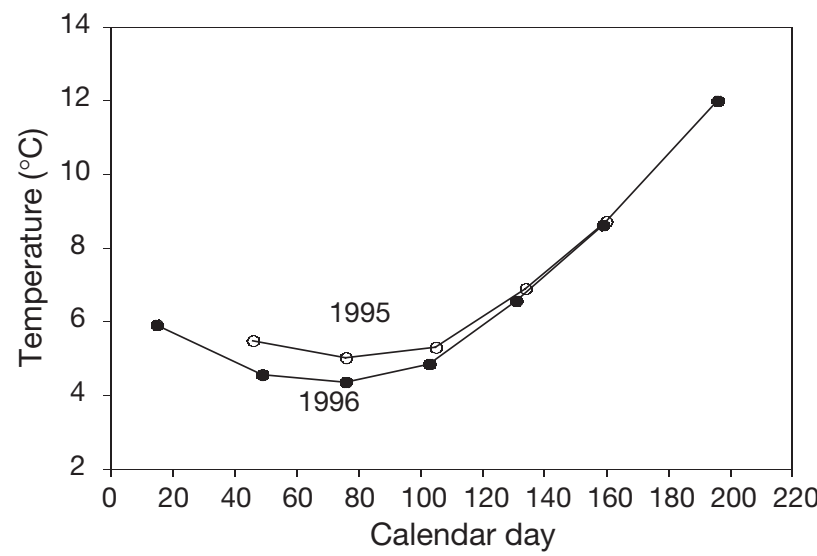

Fig. 9. Water column temperature $(0-30 \mathrm{~m})$ integrated across Georges Bank maturation of the first cohort of adult females for the year by about 1 to $2 \mathrm{wk}$. This, in turn, would delay production of nauplii and earlier copepodites so that adult Calanus finmarchicus would appear in late rather than early May. From the plots of growth for larval cod and haddock for both years, it appears that conditions over all in 1996 favored more rapid growth than in 1995. Monthly growth of cod in February and March of 1995 is higher, as suggested by greater slopes, although the difference between slopes for February 1995 and 1996 is not significant (see Fig. 3). However, later in the season in April and May, the slopes of the length-at-age regressions are significantly greater for 1996 ( $\mathrm{p}=$ 0.0058 and $\mathrm{p}<0.0001$, respectively). No significant differences in the slopes of the length-at-age regressions for haddock were evident for March or April between 1995 and 1996. There were insufficient data on haddock for comparisons between years for February and June.

In a study of larval cod and haddock trophodynamics from 1995 GLOBEC broad-scale surveys, Green et al. (1997) showed that there is a transition from feeding predominantly on nauplii and copepodites in April to preying on copepodites and adults of Calanus finmarchicus in May. The occurrence of larger prey items in the gut was correlated with increase in larval size. It is likely that the substantially increased growth rates of cod observed in April and May of 1996 after slower growth in March reflect the cooler temperatures earlier in the larval period and the more rapid increase in temperatures in April and May, coupled with increased abundance of early copepodites in April and later copepodites in May. It is also possible that the lower numbers of larvae would experience enhanced feeding conditions in late spring of 1996 due to a lack of intra-specific competition but this condition, if it occurs in organisms as low in abundance as fish larvae, would be difficult to evaluate. Thus, the minimum winter temperatures through March of 1996, which were 1.5 to $2.0^{\circ} \mathrm{C}$ colder than in 1995 , may have depressed growth rates relative to those measured for the same period of 1995.

Compared to 1995, larval growth early in 1996 appears to have been inhibited by lower temperatures, but after March the temperature differences between the 2 years disappear. After this point, the effect of the differences in mean temperatures between the 2 years may not have been manifest as metabolic effects only. Durbin et al. (2000) point out that the range of temperatures and the timing of vernal warming appear to affect the development of Calanus finmarchicus. Thus, prey availability may interact with the metabolic effects of temperature (Laurence et al. 1981, Otterlei et al. 1999, Buckley et al. 2004) in determining growth rates in later stage larvae. Campana \& Hurley (1989) 
noted that residual analysis of their temperature mediated growth model showed some evidence of trends in residuals as larvae approach the limits of their availability to sampling gear, and suggested the possibility that food availability may be a significant variable in addition to temperature in predicting growth, especially at the extremes of the growth curves.

Planque \& Fredou (1999) examined temperaturerecruitment relationships in cod and suggest a negative relationship between recruitment and increased temperature for stocks in warm waters and a positive relationship in cold waters. Both cod and haddock are close to the southernmost extension of their range in the western Atlantic (Morse et al. 1987) and are in highly productive waters (O'Reilly et al. 1987) that have supported large commercial fisheries for both species. The apparent temperature limitations to recent growth based on RNA/DNA as indicated by Buckley et al. (2004) and the results of this study suggest that effects of climatic warming may be realized at least partially via the increased food needs of larvae as waters warm. The effect of climate change may be manifest in terms of the timing of development of both predator and prey species such that suitable prey may not be available during critical periods in larval fish development. This is suggested by the evidence of a decreased growth response with seasonal warming in 1995 that was most obvious in May. Conversely, in 1996 with cooler winter minimum temperatures and a delayed cohort of Calanus finmarchicus, faster growth of cod is correlated with a higher abundance of prey, even though by May of 1996 the temperatures had warmed to those of May 1995. Availability of food, especially during the warming conditions at the end of the larval period, may limit growth, particularly in May.

The objective of this study has been to determine growth rates for cod and haddock larvae during the first $2 \mathrm{yr}$ of the GLOBEC Georges Bank Broad-scale Surveys. The study has provided monthly information on the larval populations on a bank-wide scale and allowed for comparison of growth rates among months and between years. The relatively short monthly periods of growth that were sampled in this study made it convenient to model growth in each month by using linear regression techniques that readily accommodate statistical comparisons of growth rates between months for each year. Comparisons of growth rates for cod showed conditions for growth were somewhat better in March of 1995 than in 1996, but better in April and May of 1996. Growth rates reported here for larval cod are generally higher than those reported by Bolz \& Lough $(1983,1988)$. Insufficient growth data on haddock were available to make similar comparisons. Previous work on Georges Bank (Bolz \& Lough 1983, 1988,
Campana \& Hurley 1989) has relied on combining results of multiple years of sampling over broad areas and as such, is useful as a general description of larval growth, but not as a means of understanding growth in the context of limiting conditions (i.e. temperature, food availability and predation) that can be expected to vary over time and space. Differences in growth rates between 1995 and 1996 were found to be correlated with cooler temperatures early in 1996 which appeared to slow growth relative to 1995 but also delayed the development of the second cohort of Calanus finmarchicus so that prey were more abundant later in 1996 when temperature differences were gone. Growth of cod larvae was greater later in 1996 (April and May) than in 1995. The growth parameters derived in this study reflect the predominant abundance of early larvae. Very few specimens older than $60 \mathrm{~d}$ were taken. Larvae within the first few days after hatching were not available for growth analysis, possibly due to extrusion from sampling nets. The typically high mortality during the larval stage, advection and net avoidance are likely to have made older individuals relatively rare in this as well as in previous studies of larval cod and haddock growth on Georges Bank, (e.g. Bolz \& Lough 1983, 1988, Campana \& Hurley 1989). Thus, growth rates of cod and haddock larvae on Georges Bank have been shown to vary through the larval period and between years, and relatively short periods of more rapid growth appear to be correlated with temperature and availability of suitable prey.

Acknowledgements. The authors wish to acknowledge the invaluable assistance of the officers and crews and GLOBEC Broad-scale Surveys sea-going scientific team on the RV 'Albatross IV', the RV 'Endeavor' and the RV 'Oceanus' for their perseverance and hard work on the many sea days necessary to complete this study. We also thank A. Chute and B. Burns for their efforts in the early stages of this work, D. Johnson for data on larval broad-scale distribution and abundance, and D. Busch for editing. This is US GLOBEC contribution number 444 .

\section{LITERATURE CITED}

Bailey KM, Houde ED (1989) Predation on eggs and larvae of marine fishes and the recruitment problem. Adv Mar Biol 25:1-83

Bisagni JJ, Beardsley RC, Ruhsam CM, Manning JP, Williams WJ (1996) Historical and recent evidence of Scotian Shelf water on southern Georges Bank. Deep-Sea Res II 43: 1439-1471

Bolz GR, Lough RG (1983) Growth of Atlantic cod (Gadus morhua) and haddock (Melanogrammus aegelfinus) on Georges Bank. Spring 1981 Fish Bull 81:827-836

Bolz GR, Lough RG (1988) Growth through the first six months of Atlantic cod, (Gadus morhua) and haddock (Melanogrammus aeglefinus), based on daily otolith increments. Fish Bull 86:223-235

Brett JR (1979) Enviromental factors and growth. In: Hoar WS, 
Randall DJ, Brett JR (eds) Fish physiology, Vol 8. Academic Press, New York, p 599-675

Brothers EB, Mathews CP, Lasker R (1976) Daily growth increments in otoliths from larval and adult fishes. Fish Bull 74:1-8

Buckley LJ, Caldarone EM, Lough RG (2004) Optimum temperature and food limited growth of marine fish larvae. Fish Oceanogr 13(2):134-140

Buckley LJ, Lough RG (1987) Recent growth, biochemical composition, and prey field of larval haddock (Melanogrammus aeglefinus) and Atlantic cod (Gadus morhua) on Georges Bank. Can J Fish Aquat Sci 44:14-25

Campana SE, Hurley PCF (1989) An age- and temperaturemediated growth model for cod (Gadus morhua) and haddock (Melanogrammus aeglefinus) larvae in the gulf of Maine. Can J Fish Aquat Sci 46:603-613

Colton J, Marak R (1969) Guides for identifying the common planktonic fish eggs and larvae of continental shelf water, Cape Sable to Block Island. US Bur Comm Fish Biol Lab Ref Doc 69-9, Marine Biology Laboratory, Woods Hole, MA

Cushing DH (1990) Plankton production and year-class strength in fish populations: an update of the match/mismatch hypothesis. Adv Mar Ecol 26:249-292

Durbin E, Garrahan P, Casas M (2000) Abundance and distribution of (Calanus finmarchicus) on the Georges Bank during 1995 and 1996. ICES J Mar Sci 57:1664-1685

Ellertsen B, Moksness E, Solemdal P, Tilseth S, Westgard T, Oistad V (1981) Growth and survival of cod larvae in an enclosure, experiments and a mathematical model. Rapp P-V Reun Cons Int Explor Mer 178:45-57

Geffen AJ (1995) Growth and otolith microstructure of cod (Gadus morhua L.) larvae. J Plankton Res 17:783-800

Green JR, Chute AS, Jones RJ (1997) Trophodynamics of cod and haddock larvae from GLOBEC broadscale studies on Georges Bank. (Abstract) ICES CM 1997:160

Hewitt RP, Theilacker GH, Lo NCH (1985) Causes of mortality in young jack mackerel. Mar Ecol Prog Ser 26:1-10

Hjort J (1914) Fluctuations in the great fisheries of northern Europe viewed in the light of biological research. Rapp P-V Reun Cons Int Explor Mer 20:1-288

Houde ED (1997) Patterns and consequences of selective processes in teleost early life histories. In: Chambers RC, Trippel EA (eds) Early life history and recruitment of fish populations. Chapman \& Hall, London, p 173-176

Jeffrey JA, Taggart CT (2000) Growth variation and water mass associations of larval silver hake (Merluccius bilinearis) on the Scotian Shelf. Can J Fish Aquat Sci 57:1728-1738

Laurence GC (1978) Comparative growth, respiration and delayed feeding abilities of larval cod (Gadus morhua) and haddock (Melanogrammus aeglefinus) as influenced by temperature during laboratory studies. Mar Biol 50:1-7

Laurence GC, Lough RG (1985) Growth and survival of larval fishes in relation to the trophodynamics of Georges Bank cod and haddock. NOAA Tech Memo NMFS-F/NEC, $36: 1-150$

Laurence GC, Smigielski TA, Halavik TA, Burns BR (1981) Implications of direct competition between larval cod (Gadus morhua) and haddock (Melanogrammus aeglefinus) in laboratory growth and survival studies at different food densities. Rapp P-V Reun Cons Int Explor Mer 178: $304-311$

Editorial responsibility: Kenneth Sherman (Contributing Editor), Narragansett, Rhode Island, USA
Leak JC, Houde ED (1987) Cohort growth and survival of bay anchovy Anchoa mitchilli in Biscayne Bay Florida. Mar Ecol Prog Ser 37:109-122

Leising AW, Franks JS (1999) Larval Atlantic cod (Gadus morhua) and haddock (Melanogrammus aeglefinus) growth on Georges Bank: a model with temperature, prey size, and turbulent forcing. Can J Fish Aquat Sci 56:25-36

Morse WW, Fahay MP, Smith WG (1987) MARMAP surveys of the continental shelf from Cape Hatteras, North Carolina, to Cape Sable, Nova Scotia (1977-1984). Atlas No. 2. Annual distribution patterns of fish larvae. NOAA Tech Memo NMFS-F/NEC 47:1-215

O'Reilly JE, Evans-Zetlin CA, Busch DA (1987) Primary production. In: Backus RH (ed) Georges Bank. MIT Press, Cambridge, MA, p 220-223

Otterlei E, Nyhammer G, Folkvord A, Stefansson SO (1999) Temperature and size dependent growth of larval and early juvenile Atlantic cod (Gadus morhua): a comparative study of Norwegian coastal cod and Northeast Arctic cod. Can J Fish Aquat Sci 56:2099-2111

Pannella G (1971) Fish otoliths: daily growth layers and periodic patterns. Science 173:1124-1127

Planque B, Fredou T (1999) Temperature and the recruitment of Atlantic cod (Gadus morhua). Can J Fish Aquat Sci 56:2069-2077

Quinonez-Velazquez C (1999) Age validation and growth of larval and juvenile haddock, Melanogrammus aeglefinus and Pollock, Pollachius virens, on the Scotian Shelf. Fish Bull 97:306-319

Ratke RL (1989) Larval fish age, growth, and body shrinkage: information available from otoliths. Can J Fish Aquat Sci 46:1884-1894

Rilling GC, Houde ED (1999) Regional and temporal variability in growth and mortality of the bay anchovy Anchoa mitchilli larvae in Chesapeake Bay. Fish Bull 97:555-569

Secor DH, Dean JM, Laban EH (1992) Otolith removal and preparation for microstructural examination. Can J Fish Aquat Sci Spec Publ 117:19-57

Sherman K, Smith WG, Morse WW, Berman MS, Green JR, Ejsymont L (1984) Spawning strategies of fishes in relation to circulation, phytoplankton production, and pulses in zooplankton off the northeastern United States. Mar Ecol Prog Ser 18:1-19

Sinclair M (1988) Marine populations: An essay on population regulation and speciation. Washington Sea Grant program. University of Washington Press, Seattle, WA, p 252

Stevenson D, Campana SE (1992) Otolith microstructure examination and analysis. Can J Fish Aquat Sci Spec Publ 117:117-126

Theilacker G (1980) Changes in body measurements of larval northern anchovy (Engraulis mordax) and other fishes due to handling and preservation. Fish Bull 78:685-692

US GLOBEC (1991) Initial science plan. US Global Ocean Ecosystems Dynamics Rep no 1, February 1991. GLOBEC Steering Comm Joint Oceanographic Inst, Washington, DC, $p 93$

US GLOBEC (1992) Northwest Atlantic implementation plan. US Global Ocean Ecosystems Dynamics Rep no 6, June 1992. US GLOBEC Scientific Steering Comm Coordinating Office, University of California, Davis, CA, p 69

Werner FE, Perry RI, Lough RG, Naimie CE (1996) Trophodynamics and advective influences on Georges Bank larval cod and haddock. Deep-Sea Res II 43:1793-1822

Submitted: November 4, 2002; Accepted: June 28, 2004

Proofs received from author(s): November 15, 2004 